\title{
Toughness enhancement in TiAlN-based quarternary alloys
}

Davide Sangiovanni, Valeriu Chirita and Lars Hultman

\section{Linköping University Post Print}

N.B.: When citing this work, cite the original article.

Original Publication:

Davide Sangiovanni, Valeriu Chirita and Lars Hultman, Toughness enhancement in TiAlNbased quarternary alloys, 2012, Thin Solid Films, (520), 11, 4080-4088.

http://dx.doi.org/10.1016/j.tsf.2012.01.030

Copyright: Elsevier

http://www.elsevier.com/

Postprint available at: Linköping University Electronic Press

http://urn.kb.se/resolve?urn=urn:nbn:se:liu:diva-77336 


\title{
Toughness enhancement in TiAIN-based quarternary alloys
}

D. G. Sangiovanni ${ }^{\mathrm{a}}$, V Chirita ${ }^{\mathrm{b}}$, and L. Hultman ${ }^{\mathrm{c}}$

Thin Film Physics, Department of Physics, Chemistry and Biology (IFM), Linköping

University, SE-581 83 Linköping, Sweden

e-mails: ${ }^{a}$ davsan@ifm.liu.se, ${ }^{b}$ vio@ifm.liu.se, ${ }^{c}$ larhu@ifm.liu.se

Corresponding author: Davide G. Sangiovanni, Tel. 004613282623 , Fax 004613137568

\begin{abstract}
Improved toughness in hard and superhard thin films is a primary requirement for present day ceramic hard coatings, known to be prone to brittle failure during in-use conditions. We use density functional theory (DFT) calculations to investigate a number of $(\mathrm{TiAl})_{1-x} \mathrm{M}_{x} \mathrm{~N}$ thin films in the B1 structure, with $0.06 \leq x \leq 0.75$, obtained by alloying TiAlN with $\mathrm{M}=\mathrm{V}, \mathrm{Nb}$, Ta, Mo and W. Results show significant ductility enhancements, hence increased toughness, in these compounds. Importantly, these thin films are also predicted to be superhard, with similar or increased hardness values, compared to $\mathrm{Ti}_{0.5} \mathrm{Al}_{0.5} \mathrm{~N}$. For $(\mathrm{TiAl})_{1-x} \mathrm{~W}_{x} \mathrm{~N}$ the results are experimentally confirmed. The ductility increase originates in the enhanced occupancy of $d$ $t_{2 g}$ metallic states, induced by the valence electrons of substitutional elements ( $\mathrm{V}, \mathrm{Nb}, \mathrm{Ta}, \mathrm{Mo}$, W). This effect is more pronounced with increasing valence electron concentration (VEC), and, upon shearing, leads to the formation of a layered electronic structure in the compound material, consisting of alternating layers of high and low charge density in the metallic sublattice, which in turn, allows a selective response to normal and shear stresses.
\end{abstract}

Keywords: Nitrides; TiAlN; Hardness; Toughness; Ductility; DFT; Metals; Quarternaries. 


\section{Introduction}

Toughness, defined as the ability of a material to resist crack initiation and propagation up to its fracture point $[1,2]$, is one of the most important material properties. In fact, for the many applications where coatings are used to protect and/or enhance performance, toughness is a primary requirement for the reliability and safe operation of critical components. Ceramics, known for millennia as outstandingly resistant to heat, corrosion and wear, are extensively used presently as thin film coatings in electronic, energy, automotive, aeronautical, and machining applications. Impressive progress has been achieved within the last decades in the design of hard (hardness $\geq 20 \mathrm{GPa}$ ), superhard ( $\geq 40 \mathrm{GPa}$ ), and ultrahard ( $\geq 80 \mathrm{GPa}$ ) coatings [3-7], yet, given the inherent brittleness of ceramics [8, 9], modern hard ceramic thin film coatings are prone to brittle failure, particularly during in-use conditions $[10,11]$, for example in cutting tool applications.

Increased hardness/strength alone, typically translating to a corresponding increase in brittleness, will not prevent brittle failure [12-14]. Thin film hardness has to be matched by parallel enhanced toughness, which equates to increased ductility, condition which represents the only solution to coatings failure in modern applications [15-18]. Attaining simultaneous improvements in thin film coatings hardness and toughness represents, however, a formidable materials science challenge. Primarily, this is due to the fact that crack nucleation, propagation, and fracture behavior in thin films are significantly different than in their bulk counterparts $[19,20]$. In addition, on a more fundamental level, the electronic origins of brittleness and ductility are still not known, and only recently has scientific interest migrated in this direction $[21,22]$.

In pursuit of this challenge, we recently reported significant toughness/ductility enhancements in a number of $\mathrm{B} 1$ cubic TiN- and VN-based ternary nitrides, obtained by alloying with V, Nb, Ta, Mo and $\mathrm{W}[23,24]$. Therein we demonstrated that ductility increase 
originates in the enhanced occupancy of $d-t_{2 \mathrm{~g}}$ metallic states, induced by the valence electrons of substitutional elements $(\mathrm{V}, \mathrm{Nb}, \mathrm{Ta}, \mathrm{Mo}, \mathrm{W})$. The effect is more pronounced with increasing valence electron concentration (VEC), and, upon shearing, leads to the formation of a layered electronic structure, consisting of alternating layers of high and low charge density in the metallic sublattice. This, in turn, allows a selective response to tetragonal and trigonal deformation: if compressive/tensile stresses are applied, the structure responds in a "hard" manner by resisting deformation, while upon the application of shear stresses, the layered electronic arrangement is formed, bonding is changed accordingly, and the structure responds in a "ductile/tough" manner as dislocation glide along the $\{110\}\langle 1 \overline{1} 0\rangle$ slip system becomes energetically favored.

Based on the promising results obtained for TiN- and $\mathrm{VN}$-based ternaries, in this paper we expand our density functional theory (DFT) investigation to TiAlN-based alloy coatings. This choice is motivated by the potential to improve on multifunctionality of materials, as the refractory TiAlN system exhibits resistance to oxidation and wear, as well as age hardening by spinodal decomposition [3]. Ab-initio results of mechanical properties, from hardness to a complete set of elastic moduli, are reported for $\mathrm{B} 1$ cubic $(\mathrm{TiAl})_{1-\mathrm{x}} \mathrm{V}_{\mathrm{x}} \mathrm{N},(\mathrm{TiAl})_{1-\mathrm{x}} \mathrm{Nb}_{\mathrm{x}} \mathrm{N}$, $(\mathrm{TiAl})_{1-\mathrm{x}} \mathrm{Ta}_{\mathrm{x}} \mathrm{N},(\mathrm{TiAl})_{1-\mathrm{x}} \mathrm{Mo}_{\mathrm{x}} \mathrm{N}$ and $(\mathrm{TiAl})_{1-\mathrm{x}} \mathrm{W}_{\mathrm{x}} \mathrm{N}$, in the $0.06 \leq \mathrm{x} \leq 0.75$ compositional range. Our calculations point to substantial ductility/toughness enhancements with increasing concentrations for all alloying combinations. Significantly, the toughness improvement effect is predicted to occur in all compounds at comparable or increased hardness values, compared with those of $\mathrm{Ti}_{0.5} \mathrm{Al}_{0.5} \mathrm{~N}$. Theoretical predictions are in excellent agreement with experimental results obtained for $\left(\mathrm{Ti}_{0.5} \mathrm{Al}_{0.5}\right)_{1-\mathrm{x}} \mathrm{W}_{\mathrm{x}} \mathrm{N}$ over most of the concentration range.

\section{Methodology}

As in our preceding studies, DFT calculations are performed with the VASP code [25] 
in the generalized gradient approximation (GGA) of Perdew and Wang [26], and electron-ion interactions described with projector augmented wave potentials (PAW) [27]. We use $\left(\mathrm{Ti}_{0.5} \mathrm{Al}_{0.5}\right)_{1-x} \mathrm{M}_{x} \mathrm{~N}$ simulation supercells consisting of 64 atoms, as shown in Fig. 1, with substitutional transition metal concentrations $0 \leq x \leq 0.75$. The arrangement of metal planes on the sublattice in our model structure is closely related to CuPt-type ordering, as used for TiN- and VN-based ternaries [23, 24], and observed experimentally in $\mathrm{Ti}_{\mathrm{x}} \mathrm{W}_{1-\mathrm{x}} \mathrm{N}$ films [28]. To retain close to cubic symmetry at different chemical compositions, atoms are appropriately rearranged on metal sublattice sites. Extensive tests, at different concentrations, show that changes in the ordering of substitutional atoms on the metal sublattice have a negligible effect on the elastic properties of alloys. Total energies are evaluated to an accuracy of $10^{-5} \mathrm{eV} /$ atom with a large plane wave basis set energy cutoff of $500 \mathrm{eV}$, and the Brillouin zone is sampled with 4 x 4 x 4 k-point grids in the Monkhorst-Pack scheme [29]. For density of states (DOS), charge density distribution and crystal orbital overlap population (COOP) [30] calculations, we use 8 × 8 × $8 \mathbf{k}$-point grids.

Lattice parameters $a$, bulk moduli $B$, elastic constants $C_{11}, C_{12}$, and $C_{44}$, elastic moduli $G$ and $E$, and Poisson's ratios $v$ are calculated as previously described [23]. Similarly, to predict Knoop $\left(H_{\mathrm{K}}\right)$ and Vickers $\left(H_{\mathrm{V}}\right)$ hardness, we use the models proposed by Šimůnek [31], respectively Guo [32], as detailed in our previous paper [24]. Typically, COOP analysis is used to estimate the covalent character of chemical bonds in solids by partitioning the eigenfunctions into neighboring atoms molecular orbitals. The method thus yields the overlap population weighted density of states, from which bonding and anti-bonding states are identified as positive, respectively negative, COOP values. The relative covalent bond strengths are obtained by integrating up to the Fermi level (ICOOP values). Overlap population integrals are evaluated on the overlaying portions of spheres centered at atom sites. Each sphere radius is proportional to the respective atomic covalent radius, and the volumes 
of all spheres sum up to the supercell volume. The atomic orbitals overlap used in the COOP and Vickers hardness calculations reported herein, are shown in Fig. 2. Further details can be found in references [24, 33].

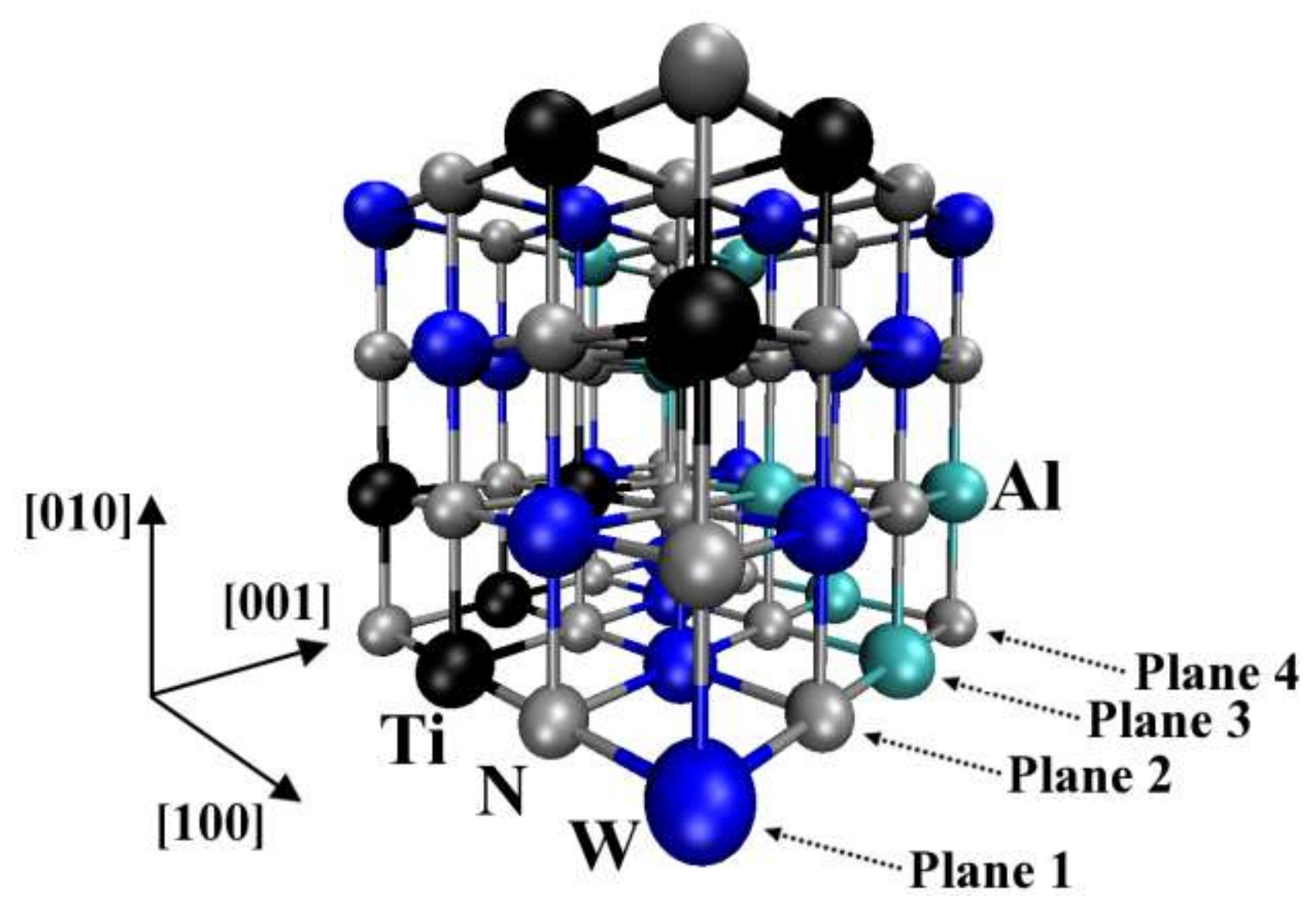

Figure 1. (Color online) 64-atom supercells used in VASP calculations, illustrating here the $\mathrm{Ti}_{0.25} \mathrm{Al}_{0.25} \mathrm{~W}_{0.5} \mathrm{~N}$ configuration. Also shown, the atomic plane cuts used in charge density analysis.

\section{Results and discussion}

The results of ab-initio calculated mechanical properties, for each $\left(\mathrm{Ti}_{0.5} \mathrm{Al}_{0.5}\right)_{1-x} \mathrm{M}_{x} \mathrm{~N}$ alloying combination $\mathrm{M}=\mathrm{W}, \mathrm{V}, \mathrm{Nb}$, Ta, and Mo, are listed in this order in Tables $1-5$. In each case, calculations address alloying metal concentrations of $x=0.0625,0.125,0.25,0.50$, $0.625,0.75$, and as a reference point, the tables include $\mathrm{Ti}_{0.5} \mathrm{Al}_{0.5} \mathrm{~N}$ properties. In addition, to serve as comparison, tables present the existing DFT and/or experimental values in compounds with similar compositions. As a first observation, we note the excellent agreement between our theoretical predictions and the available experimental data, primarily related to 
First Neighbor

$\mathrm{N}-$ metal

$\sigma \quad s-s$

$\sigma \quad s-p$

$\sigma \quad s-d-e_{g}$

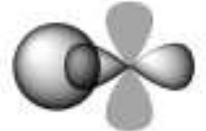

$\sigma \boldsymbol{p}-\boldsymbol{s}$

$\sigma \boldsymbol{p}-\boldsymbol{p}$

$\sigma p-d-e_{g}$

$\pi p-p$

$\pi p-d-t_{2 g}$

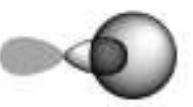

(
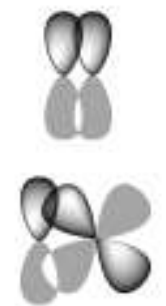

Second Neighbor

metal-metal

Q $\sigma s-s$

Q $\sigma s-d-t_{2 g}$

$\infty$

Figure 2. Schematic view of orbitals overlap, with "metal" used as tag for $\mathrm{Al}, \mathrm{Ti}$, and /V/Nb/Ta/Mo/W.

lattice constant estimations, Young modulus and Vickers hardness measurements in most compounds. This fact is reflected in Table 1, which demonstrates that our DFT estimations are confirmed by experimentally determined $a, E$ and $H_{\mathrm{V}}$ values in recently synthesized TiAlN-WN $\mathrm{W}_{x}$ thin films throughout the alloying concentration range [34]. For the other $\left(\mathrm{Ti}_{0.5} \mathrm{Al}_{0.5}\right)_{1-x} \mathrm{M}_{x} \mathrm{~N}$ combinations, as shown in Tables $2-5$, our ab-initio predictions are still closely matched to experimental findings [35-40], even though chemical compositions in most cases do not correspond to those in our calculations as in the case of W. We note that 
TABLE 1 .

Present work DFT calculated mechanical properties of $\left(\mathrm{Ti}_{0.5} \mathrm{Al}_{0.5}\right)_{1-x} \mathrm{~W}_{x} \mathrm{~N}$ alloys, including, where available, reported $a b$-initio and experimental data.

\begin{tabular}{|c|c|c|c|c|c|c|c|c|c|c|c|}
\hline & $\begin{array}{c}a \\
(\AA)\end{array}$ & $\begin{array}{c}E \\
(\mathrm{GPa})\end{array}$ & $\begin{array}{c}H_{\mathrm{V}} \\
(\mathrm{GPa})\end{array}$ & $\begin{array}{c}B \\
(\mathrm{GPa})\end{array}$ & $\begin{array}{c}G \\
(\mathrm{GPa})\end{array}$ & $\begin{array}{c}C_{44} \\
(\mathrm{GPa})\end{array}$ & $\begin{array}{c}C_{11} \\
(\mathrm{GPa})\end{array}$ & $\begin{array}{c}C_{12} \\
(\mathrm{GPa})\end{array}$ & $v$ & $\begin{array}{c}C_{12} C_{44} \\
(\mathrm{GPa})\end{array}$ & $G / B$ \\
\hline $\mathrm{Ti}_{0.5} \mathrm{Al}_{0.5} \mathrm{~N}$ & $\begin{array}{l}4.175 \\
4.165^{\mathrm{a}} \\
4.171^{\mathrm{b}}\end{array}$ & $\begin{array}{l}440 \\
410^{\mathrm{a}} \\
440^{\mathrm{b}}\end{array}$ & $\begin{array}{c}29.4 \\
30^{\mathrm{a}}\end{array}$ & 269 & 179 & 189 & 488 & 159 & 0.227 & -30 & 0.665 \\
\hline $\mathrm{Ti}_{0.47} \mathrm{Al}_{0.47} \mathrm{~W}_{0.06} \mathrm{~N}$ & 4.183 & 436 & 28.3 & 274 & 177 & 180 & 503 & 160 & 0.235 & -20 & 0.646 \\
\hline $\mathrm{Ti}_{0.44} \mathrm{Al}_{0.44} \mathrm{~W}_{0.12} \mathrm{~N}$ & $\begin{array}{l}4.197 \\
4.22^{\mathrm{c}}\end{array}$ & $\begin{array}{l}415 \\
430^{c}\end{array}$ & $\begin{array}{c}32.4 \\
34^{\mathrm{c}}\end{array}$ & 277 & 166 & 155 & 520 & 155 & 0.250 & 0 & 0.599 \\
\hline $\mathrm{Ti}_{0.375} \mathrm{Al}_{0.375} \mathrm{~W}_{0.25} \mathrm{~N}$ & $\begin{array}{l}4.224 \\
4.21^{\mathrm{c}} \\
4.23^{\mathrm{c}}\end{array}$ & $\begin{array}{c}398 \\
400^{c}\end{array}$ & $\begin{array}{c}30.6 \\
29^{c}\end{array}$ & 282 & 157 & 133 & 540 & 153 & 0.265 & 20 & 0.557 \\
\hline $\mathrm{Ti}_{0.25} \mathrm{Al}_{0.25} \mathrm{~W}_{0.5} \mathrm{~N}$ & $\begin{array}{l}4.271 \\
4.24^{\mathrm{c}} \\
4.25^{\mathrm{c}}\end{array}$ & $\begin{array}{c}371 \\
380^{\mathrm{c}}\end{array}$ & $\begin{array}{c}31.9 \\
30^{\mathrm{c}}\end{array}$ & 306 & 143 & 139 & 504 & 207 & 0.298 & 68 & 0.467 \\
\hline $\mathrm{Ti}_{0.19} \mathrm{Al}_{0.19} \mathrm{~W}_{0.62} \mathrm{~N}$ & $\begin{array}{l}4.291 \\
4.24^{\mathrm{c}}\end{array}$ & $\begin{array}{c}349 \\
460^{c}\end{array}$ & $\begin{array}{c}28.8 \\
36^{\mathrm{c}}\end{array}$ & 315 & 133 & 98 & 561 & 192 & 0.315 & 94 & 0.422 \\
\hline $\mathrm{Ti}_{0.125} \mathrm{Al}_{0.125} \mathrm{~W}_{0.75} \mathrm{~N}$ & $\begin{array}{l}4.314 \\
4.24^{\mathrm{c}}\end{array}$ & $\begin{array}{c}325 \\
400^{c}\end{array}$ & $\begin{array}{c}26.6 \\
30^{\mathrm{c}} \\
36^{\mathrm{c}}\end{array}$ & 326 & 139 & 95 & 541 & 219 & 0.334 & 124 & 0.373 \\
\hline
\end{tabular}

$$
\begin{aligned}
& \mathrm{a}=\operatorname{ref} .34, \exp \\
& \mathrm{b}=\operatorname{ref} .34, \text { ab-initio } \\
& \mathrm{c}=\operatorname{ref} .33, \exp
\end{aligned}
$$


TABLE 2 .

Present work DFT calculated mechanical properties of $\left(\mathrm{Ti}_{0.5} \mathrm{Al}_{0.5}\right)_{1-x} \mathrm{~V}_{x} \mathrm{~N}$ alloys, including, where available, reported ab-initio and experimental data.

\begin{tabular}{|c|c|c|c|c|c|c|c|c|c|c|c|}
\hline & $\begin{array}{c}a \\
(\AA)\end{array}$ & $\begin{array}{c}E \\
(\mathrm{GPa})\end{array}$ & $\begin{array}{c}H_{\mathrm{V}} \\
(\mathrm{GPa})\end{array}$ & $\begin{array}{c}B \\
(\mathrm{GPa})\end{array}$ & $\begin{array}{c}G \\
(\mathrm{GPa})\end{array}$ & $\begin{array}{c}C_{44} \\
(\mathrm{GPa})\end{array}$ & $\begin{array}{c}C_{11} \\
(\mathrm{GPa})\end{array}$ & $\begin{array}{c}C_{12} \\
(\mathrm{GPa})\end{array}$ & $v$ & $\begin{array}{c}C_{12}-C_{44} \\
(\mathrm{GPa})\end{array}$ & $G / B$ \\
\hline $\mathrm{Ti}_{0.5} \mathrm{Al}_{0.5} \mathrm{~N}$ & 4.175 & 440 & 29.4 & 269 & 179 & 189 & 488 & 159 & 0.227 & -30 & 0.665 \\
\hline $\mathrm{Ti}_{0.47} \mathrm{Al}_{0.47} \mathrm{~V}_{0.06} \mathrm{~N}$ & 4.171 & $\begin{array}{l}438 \\
387^{\mathrm{d}} \\
383^{\mathrm{d}}\end{array}$ & $\begin{array}{l}31.2 \\
42^{\mathrm{d}}\end{array}$ & 272 & 178 & 189 & 486 & 165 & 0.232 & -24 & 0.653 \\
\hline $\mathrm{Ti}_{0.44} \mathrm{Al}_{0.44} \mathrm{~V}_{0.12} \mathrm{~N}$ & 4.169 & $\begin{array}{c}457 \\
470^{\mathrm{e}} \\
349-532^{\mathrm{f}}\end{array}$ & $\begin{array}{c}33.9 \\
43^{\mathrm{e}} \\
27.6-38^{\mathrm{f}}\end{array}$ & 275 & 187 & 179 & 540 & 143 & 0.223 & -36 & 0.680 \\
\hline $\mathrm{Ti}_{0.375} \mathrm{Al}_{0.375} \mathrm{~V}_{0.25} \mathrm{~N}$ & 4.161 & $\begin{array}{c}413 \\
350^{\mathrm{g}}\end{array}$ & $\begin{array}{c}33.3 \\
27.5^{\mathrm{g}}\end{array}$ & 277 & 165 & 158 & 511 & 160 & 0.252 & 2 & 0.596 \\
\hline $\mathrm{Ti}_{0.25} \mathrm{Al}_{0.25} \mathrm{~V}_{0.5} \mathrm{~N}$ & 4.147 & $\begin{array}{l}430 \\
340^{\mathrm{g}}\end{array}$ & $\begin{array}{l}35.3 \\
26^{\mathrm{g}} \\
40^{\mathrm{e}}\end{array}$ & 291 & 172 & 153 & 557 & 159 & 0.254 & 5 & 0.591 \\
\hline $\mathrm{Ti}_{0.19} \mathrm{Al}_{0.19} \mathrm{~V}_{0.62} \mathrm{~N}$ & 4.143 & 373 & 36.7 & 299 & 144 & 150 & 480 & 209 & 0.292 & 59 & 0.482 \\
\hline $\mathrm{Ti}_{0.125} \mathrm{Al}_{0.125} \mathrm{~V}_{0.75} \mathrm{~N}$ & 4.136 & 182 & 40.4 & 275 & 64 & 119 & 255 & 285 & 0.390 & 166 & 0.238 \\
\hline
\end{tabular}

$$
\begin{aligned}
& \text { d }=\text { ref. 35, exp } \\
& e=\text { ref. 36, exp } \\
& f=\text { ref. 37, exp } \\
& g=\text { ref. 38, exp }
\end{aligned}
$$


TABLE 3.

Present work DFT calculated mechanical properties of $\left(\mathrm{Ti}_{0.5} \mathrm{Al}_{0.5}\right)_{1-x} \mathrm{Nb}_{x} \mathrm{~N}$ alloys, including, where available, reported $a b$-initio and experimental data.

\begin{tabular}{|c|c|c|c|c|c|c|c|c|c|c|c|}
\hline & $\begin{array}{c}a \\
(\AA) \\
\end{array}$ & $\begin{array}{c}E \\
(\mathrm{GPa}) \\
\end{array}$ & $\begin{array}{c}H_{\mathrm{V}} \\
(\mathrm{GPa}) \\
\end{array}$ & $\begin{array}{c}B \\
(\mathrm{GPa}) \\
\end{array}$ & $\begin{array}{c}G \\
(\mathrm{GPa}) \\
\end{array}$ & $\begin{array}{c}C_{44} \\
(\mathrm{GPa}) \\
\end{array}$ & $\begin{array}{c}C_{11} \\
(\mathrm{GPa}) \\
\end{array}$ & $\begin{array}{c}C_{12} \\
(\mathrm{GPa}) \\
\end{array}$ & $v$ & $\begin{array}{c}C_{12}-C_{44} \\
(\mathrm{GPa})\end{array}$ & $G / B$ \\
\hline $\mathrm{Ti}_{0.5} \mathrm{Al}_{0.5} \mathrm{~N}$ & 4.175 & 440 & 29.4 & 269 & 179 & 189 & 488 & 159 & 0.227 & -30 & 0.665 \\
\hline $\mathrm{Ti}_{0.47} \mathrm{Al}_{0.47} \mathrm{Nb}_{0.06} \mathrm{~N}$ & $\begin{array}{l}4.198 \\
4.185^{\mathrm{a}}\end{array}$ & $\begin{array}{l}478 \\
505^{\mathrm{a}} \\
440^{\mathrm{b}}\end{array}$ & $\begin{array}{c}27.4 \\
36^{\mathrm{a}}\end{array}$ & 263 & 200 & 181 & 567 & 111 & 0.197 & -70 & 0.760 \\
\hline $\mathrm{Ti}_{0.44} \mathrm{Al}_{0.44} \mathrm{Nb}_{0.12} \mathrm{~N}$ & $\begin{array}{l}4.214 \\
4.199^{\mathrm{a}}\end{array}$ & $\begin{array}{c}474 \\
500^{\mathrm{a}} \\
440^{\mathrm{b}}\end{array}$ & $\begin{array}{c}30.7 \\
39.5^{\mathrm{a}}\end{array}$ & 264 & 198 & 179 & 565 & 114 & 0.200 & -65 & 0.750 \\
\hline $\mathrm{Ti}_{0.375} \mathrm{Al}_{0.375} \mathrm{Nb}_{0.25} \mathrm{~N}$ & 4.259 & 407 & 26.6 & 273 & 163 & 144 & 528 & 146 & 0.251 & 2 & 0.597 \\
\hline $\mathrm{Ti}_{0.25} \mathrm{Al}_{0.25} \mathrm{Nb}_{0.5} \mathrm{~N}$ & 4.328 & 378 & 21.2 & 276 & 149 & 116 & 540 & 144 & 0.271 & 28 & 0.540 \\
\hline $\mathrm{Ti}_{0.19} \mathrm{Al}_{0.19} \mathrm{Nb}_{0.62} \mathrm{~N}$ & 4.366 & 388 & 19.4 & 272 & 154 & 120 & 544 & 136 & 0.262 & 16 & 0.566 \\
\hline $\mathrm{Ti}_{0.125} \mathrm{Al}_{0.125} \mathrm{Nb}_{0.75} \mathrm{~N}$ & 4.402 & 295 & 18.9 & 294 & 111 & 116 & 431 & 225 & 0.333 & 109 & 0.378 \\
\hline
\end{tabular}

$$
\begin{aligned}
& \mathrm{a}=\text { ref. } 34, \exp \\
& \mathrm{b}=\text { ref. } 34, \text { ab-initio }
\end{aligned}
$$


TABLE 4.

Present work DFT calculated mechanical properties of $\left(\mathrm{Ti}_{0.5} \mathrm{Al}_{0.5}\right)_{1-x} \mathrm{Ta}_{x} \mathrm{~N}$ alloys, including, where available, reported ab-initio and experimental data.

\begin{tabular}{|c|c|c|c|c|c|c|c|c|c|c|c|}
\hline & $\begin{array}{c}a \\
(\AA)\end{array}$ & $\begin{array}{c}E \\
(\mathrm{GPa})\end{array}$ & $\begin{array}{c}H_{\mathrm{V}} \\
(\mathrm{GPa})\end{array}$ & $\begin{array}{c}B \\
(\mathrm{GPa})\end{array}$ & $\begin{array}{c}G \\
(\mathrm{GPa})\end{array}$ & $\begin{array}{c}C_{44} \\
(\mathrm{GPa})\end{array}$ & $\begin{array}{c}C_{11} \\
(\mathrm{GPa})\end{array}$ & $\begin{array}{c}C_{12} \\
(\mathrm{GPa})\end{array}$ & $v$ & $\begin{array}{c}C_{12}-C_{44} \\
(\mathrm{GPa})\end{array}$ & $G / B$ \\
\hline $\mathrm{Ti}_{0.5} \mathrm{Al}_{0.5} \mathrm{~N}$ & 4.175 & 440 & 29.4 & 269 & 179 & 189 & 488 & 159 & 0.227 & -30 & 0.665 \\
\hline $\mathrm{Ti}_{0.47} \mathrm{Al}_{0.47} \mathrm{Ta}_{0.06} \mathrm{~N}$ & $\begin{array}{l}4.196 \\
4.176^{h} \\
4.182^{\mathrm{i}}\end{array}$ & 403 & 28.6 & 271 & 161 & 161 & 485 & 164 & 0.252 & 3 & 0.594 \\
\hline $\mathrm{Ti}_{0.44} \mathrm{Al}_{0.44} \mathrm{Ta}_{0.12} \mathrm{~N}$ & $\begin{array}{l}4.214 \\
4.188^{\mathrm{h}} \\
4.205^{\mathrm{i}}\end{array}$ & 431 & 29.9 & 276 & 174 & 171 & 514 & 157 & 0.240 & -14 & 0.630 \\
\hline $\mathrm{Ti}_{0.375} \mathrm{Al}_{0.375} \mathrm{Ta}_{0.25} \mathrm{~N}$ & 4.249 & 428 & 27.1 & 283 & 172 & 149 & 557 & 146 & 0.248 & -3 & 0.608 \\
\hline $\mathrm{Ti}_{0.25} \mathrm{Al}_{0.25} \mathrm{Ta}_{0.5} \mathrm{~N}$ & 4.311 & 389 & 23.2 & 294 & 152 & 118 & 564 & 159 & 0.280 & 41 & 0.517 \\
\hline $\mathrm{Ti}_{0.19} \mathrm{Al}_{0.19} \mathrm{Ta}_{0.62} \mathrm{~N}$ & 4.341 & 333 & 21.5 & 297 & 127 & 105 & 510 & 191 & 0.313 & 86 & 0.428 \\
\hline $\mathrm{Ti}_{0.125} \mathrm{Al}_{0.125} \mathrm{Ta}_{0.75} \mathrm{~N}$ & 4.370 & 267 & 21.3 & 314 & 98 & 109 & 424 & 259 & 0.358 & 150 & 0.312 \\
\hline
\end{tabular}

$$
\begin{aligned}
& \mathrm{h}=\text { ref. } 39, \exp \\
& \mathrm{i}=\text { ref. } 39, \text { ab-initio }
\end{aligned}
$$


TABLE 5.

Present work DFT calculated mechanical properties of $\left(\mathrm{Ti}_{0.5} \mathrm{Al}_{0.5}\right)_{1-x} \mathrm{Mo}_{x} \mathrm{~N}$ alloys. No previous experimental/theoretical data available.

\begin{tabular}{|c|c|c|c|c|c|c|c|c|c|c|c|}
\hline & $\begin{array}{c}a \\
(\AA)\end{array}$ & $\begin{array}{c}E \\
(\mathrm{GPa})\end{array}$ & $\begin{array}{c}H_{\mathrm{V}} \\
(\mathrm{GPa})\end{array}$ & $\begin{array}{c}B \\
(\mathrm{GPa})\end{array}$ & $\begin{array}{c}G \\
(\mathrm{GPa})\end{array}$ & $\begin{array}{c}C_{44} \\
(\mathrm{GPa})\end{array}$ & $\begin{array}{c}C_{11} \\
(\mathrm{GPa})\end{array}$ & $\begin{array}{c}C_{12} \\
(\mathrm{GPa})\end{array}$ & $v$ & $\begin{array}{c}C_{12}-C_{44} \\
(\mathrm{GPa})\end{array}$ & $G / B$ \\
\hline $\mathrm{Ti}_{0.5} \mathrm{Al}_{0.5} \mathrm{~N}$ & 4.175 & 440 & 29.4 & 269 & 179 & 189 & 488 & 159 & 0.227 & -30 & 0.665 \\
\hline $\mathrm{Ti}_{0.47} \mathrm{Al}_{0.47} \mathrm{Mo}_{0.06} \mathrm{~N}$ & 4.185 & 438 & 27.2 & 272 & 178 & 179 & 505 & 154 & 0.232 & -25 & 0.654 \\
\hline $\mathrm{Ti}_{0.44} \mathrm{Al}_{0.44} \mathrm{Mo}_{0.12} \mathrm{~N}$ & 4.197 & 421 & 32.8 & 273 & 169 & 162 & 513 & 154 & 0.243 & -8 & 0.619 \\
\hline $\mathrm{Ti}_{0.375} \mathrm{Al}_{0.375} \mathrm{Mo}_{0.25} \mathrm{~N}$ & 4.221 & 383 & 29.4 & 279 & 151 & 130 & 522 & 158 & 0.271 & 28 & 0.541 \\
\hline $\mathrm{Ti}_{0.25} \mathrm{Al}_{0.25} \mathrm{Mo}_{0.5} \mathrm{~N}$ & 4.265 & 385 & 31.9 & 295 & 150 & 148 & 500 & 193 & 0.282 & 45 & 0.508 \\
\hline $\mathrm{Ti}_{0.19} \mathrm{Al}_{0.19} \mathrm{Mo}_{0.62} \mathrm{~N}$ & 4.286 & 352 & 29.3 & 313 & 134 & 142 & 476 & 232 & 0.313 & 90 & 0.428 \\
\hline $\mathrm{Ti}_{0.125} \mathrm{Al}_{0.125} \mathrm{Mo}_{0.75} \mathrm{~N}$ & 4.306 & 293 & 28.7 & 331 & 108 & 53 & 586 & 204 & 0.353 & 151 & 0.326 \\
\hline
\end{tabular}


structural information on ordering is not given in any of the experimental papers. Very good agreement with respect to previous DFT studies is also obtained in most cases [35, 40].

Several important trends are clear in the properties of $\left(\mathrm{Ti}_{0.5} \mathrm{Al}_{0.5}\right)_{1-x} \mathrm{M}_{x} \mathrm{~N}$ alloys presented in Tables $1-5$. In each case, the TiAlN-based quarternaries exhibit significant increases in bulk modulus values compared to the reference ternary. This $B$ increase is accompanied by decreasing elastic stiffness $E$ and shear resistance, $G$ and $C_{44}$. The effect is more pronounced with rising concentrations of $\mathrm{V}, \mathrm{Nb}$, Ta, Mo and $\mathrm{W}$, which yield higher $B$ values by up to $23 \%$, and decreased $\mathrm{E}, G$, and $C_{44}$ values of up to $45 \%$. These trends are in line with the observed changes in the properties of TiN- and VN-based ternaries obtained by alloying TiN and $\mathrm{VN}$ with $\mathrm{Nb}$, Ta, Mo, and $\mathrm{W}[23,24]$. Here, we also note that higher $\mathrm{Nb}$, $\mathrm{Ta}$, Mo, and $\mathrm{W}$ concentrations in $\mathrm{Ti}_{0.5} \mathrm{Al}_{0.5} \mathrm{~N}$ result in continually increasing lattice constants, hence an expansion of corresponding unit cell volumes. Upon alloying with $\mathrm{V}$, however, the opposite situation occurs, and the lattice parameter decreases with increasing $x$. Ultimately, $\mathrm{Ti}_{0.125} \mathrm{Al}_{0.125} \mathrm{~V}_{0.75} \mathrm{~N}$ is predicted to be mechanically unstable with respect to tetragonal deformations, as at this high concentration we find $C_{12}>C_{11}$.

The notable reductions in $C_{44}$ and $G$ shear resistance values mentioned above will clearly affect material properties such as $G / B$ ratio, Cauchy pressure $\left(C_{12}-C_{44}\right)$ and Poisson's ratio. The former two quantities are typically used to assess ductility trends in materials in conjunction with the Pettifor [41] and Pugh [42] criteria, which state that positive Cauchy pressure values and $G / B$ ratios $<0.5$ imply compliant/ductile materials. In Fig. 3 we map the ductility trends for all the alloys studied here according to these criteria. The trends observed in Fig. 3 clearly suggest that alloying $\mathrm{Ti}_{0.5} \mathrm{Al}_{0.5} \mathrm{~N}$ with $\mathrm{V}, \mathrm{Nb}$, Ta, Mo or $\mathrm{W}$ improves ductility, with best results obtained for Mo and/or W additions. We reported similar findings for TiNand $\mathrm{VN}$-based ternary alloys [24], also with $\mathrm{Mo} / \mathrm{W}$ the best candidates for enhanced ductility. As demonstrated therein, the Cauchy pressure, and hence ductility, linearly increase with 


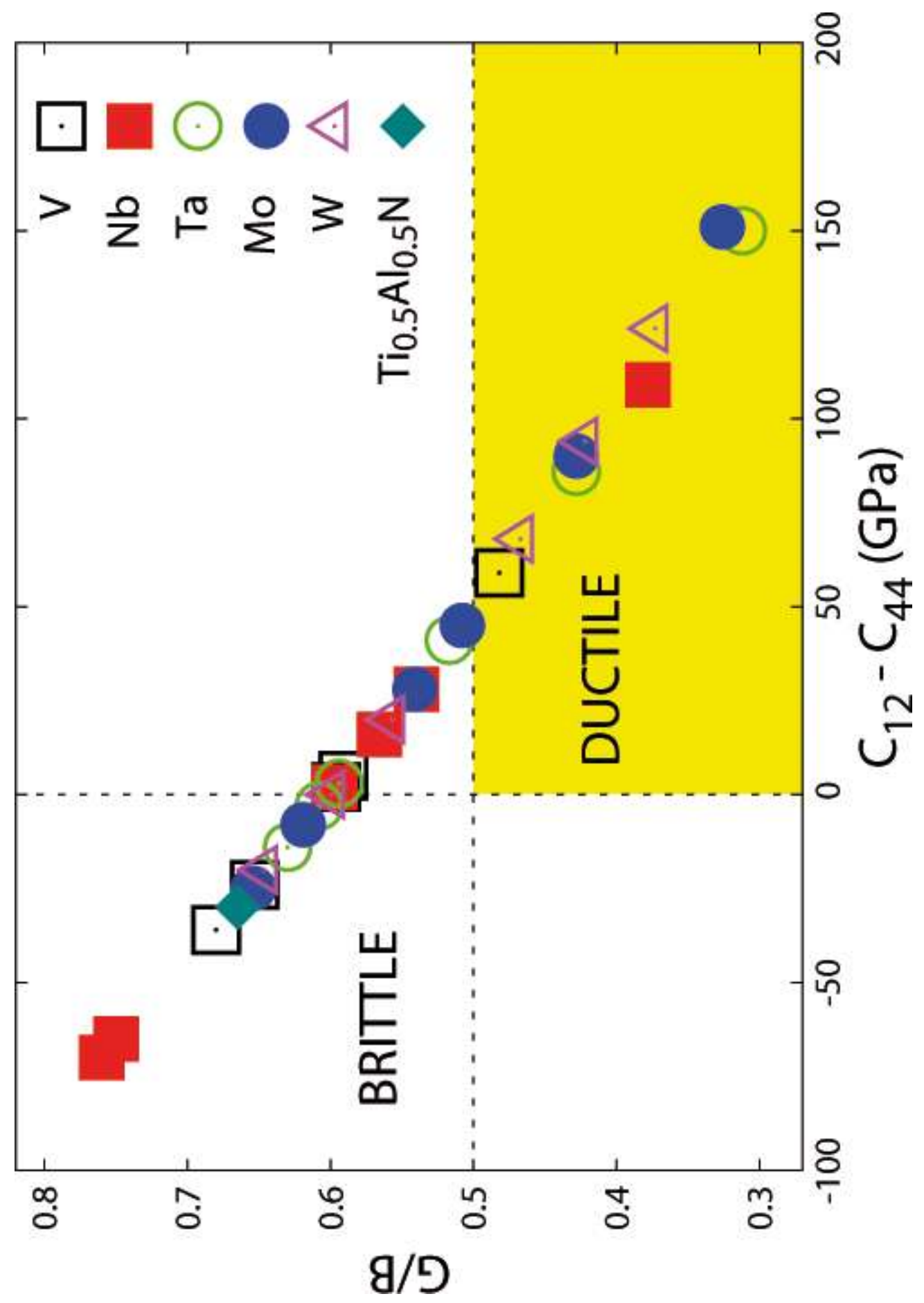

Figure 3. (Color online) Map of brittleness and ductility trends in compounds evaluated in this work.

$\mathrm{VEC}$ in the $8.5-10.5 \mathrm{e}^{-}$/cell range; while alloying with $\mathrm{Nb} / \mathrm{Ta} / \mathrm{Mo} / \mathrm{W}$ increases the VEC per unit cell, Mo/W addition results in compounds with maximum VEC values in this interval. The VEC ductility relationship in $\left(\mathrm{Ti}_{0.5} \mathrm{Al}_{0.5}\right)_{1-x} \mathrm{M}_{x} \mathrm{~N}$ alloys is shown in Fig. 4, where one can 
clearly see that the trend described for ternary alloys applies to the quarternaries discussed herein. These results confirm the reported VEC effect on ductility [24], and its role as a tunable ab-initio parameter in enhancing the ductility of compounds.

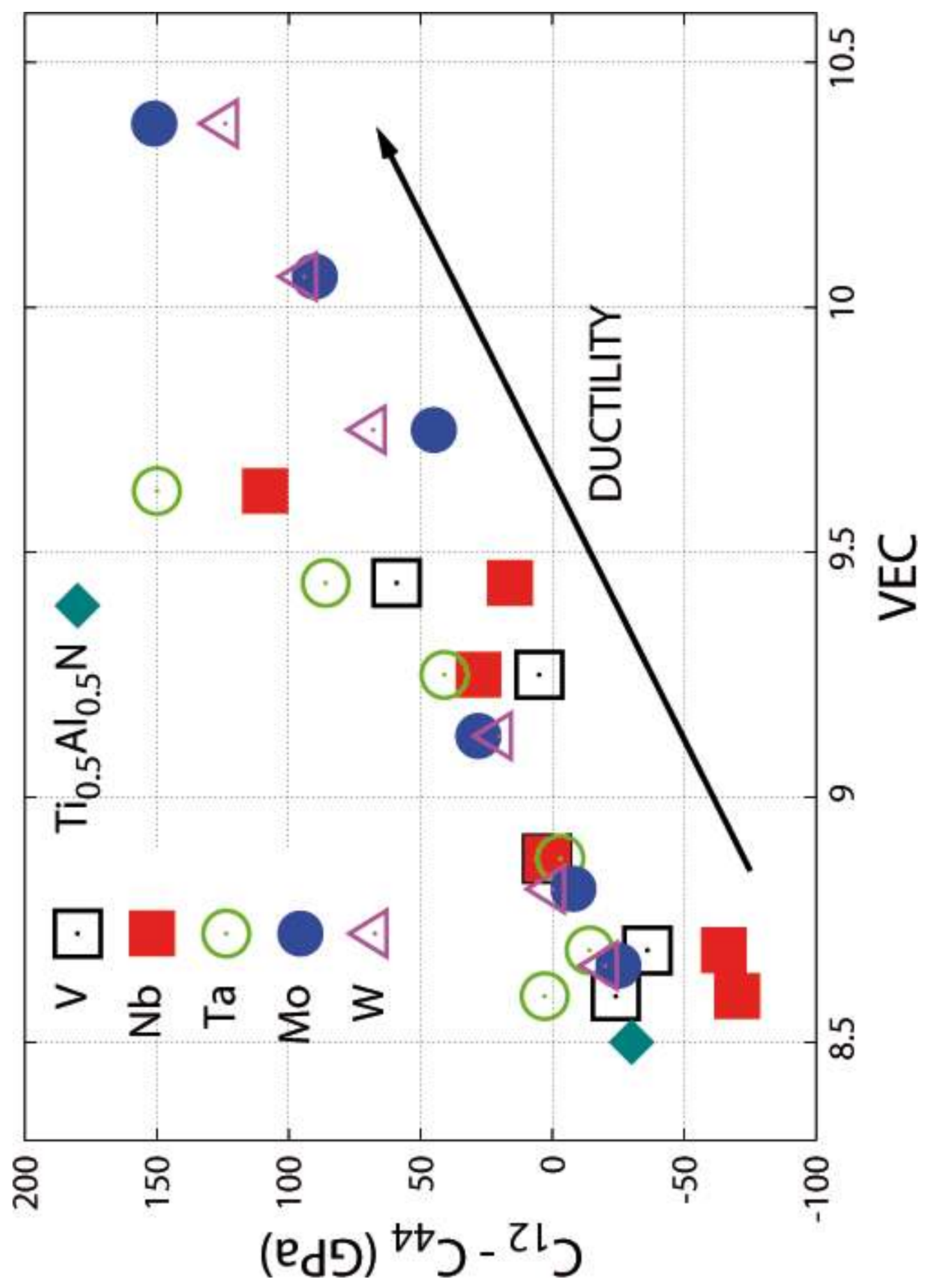

Figure 4. (Color online) VEC-induced trends in ductility and Cauchy pressure.

The second important aspect of the mechanical properties of $\left(\operatorname{Ti}_{0.5} \mathrm{Al}_{0.5}\right)_{1-x} \mathrm{M}_{x} \mathrm{~N}$ alloys considered here is hardness. As DFT calculations cannot be directly used to assess thin film 
hardness due to obvious computational resources limitations, alternative methods have been optimized to predict Knoop and Vickers hardness for a number of transition metal carbide and nitride crystals [31, 32, 43, 44]. We recently used these techniques and demonstrated that they satisfactorily account for the hardness of TiN-based thin films [24]. As in the previous study, we stress that the approaches used here are indicative of the inherent hardness of compounds and might significantly differ from thin film hardness, which depends on a large number of factors, such as microstructure through the growth conditions. It is also well known that Knoop and Vickers indentation tests use different tips, so for the same material, the respective experimental hardness values may deviate significantly. Nevertheless, our estimations can be used to qualitatively and comparatively assess the hardness of compounds considered in this study, regardless of the considered experimental technique.

The theoretically predicted Knoop and Vickers hardness values obtained for all $\left(\mathrm{Ti}_{0.5} \mathrm{Al}_{0.5}\right)_{1-x} \mathrm{M}_{x} \mathrm{~N}$ alloys and concentrations considered in this study are listed in Table 6 . As it can be seen, for each metal, theoretical Knoop hardness values increase almost linearly with alloying concentration. No similar relationship is observed for theoretical Vickers hardness. While in the case of $\mathrm{V}$, Vickers hardness increases with $x$, alloying with $\mathrm{Nb}$ and $\mathrm{Ta}$ leads to progressive decreases in hardness from $\sim 28 \mathrm{GPa}$ to $\sim 20 \mathrm{GPa}$. At the same time, Vickers hardness in Mo and $\mathrm{W}$ quarternaries does not significantly changes with alloying concentration. The most important trend emerging here, however, is that with the exception of $\mathrm{Nb}$ and $\mathrm{Ta}$ alloys at high concentrations, all quarternaries are predicted to have higher hardness than, or at least comparable with, the reference ternary, $\operatorname{Ti}_{0.5} \mathrm{Al}_{0.5} \mathrm{~N}$. This trend in hardness has been confirmed experimentally for $\mathrm{V}$ [36-39] and $\mathrm{W}$ [34] alloys, and corroborated with the ductility enhancement predicted herein, demonstrates the possibility of synthesizing hard thin films with improved toughness. 
TABLE 6.

Predicted Knoop and Vickers hardness values.

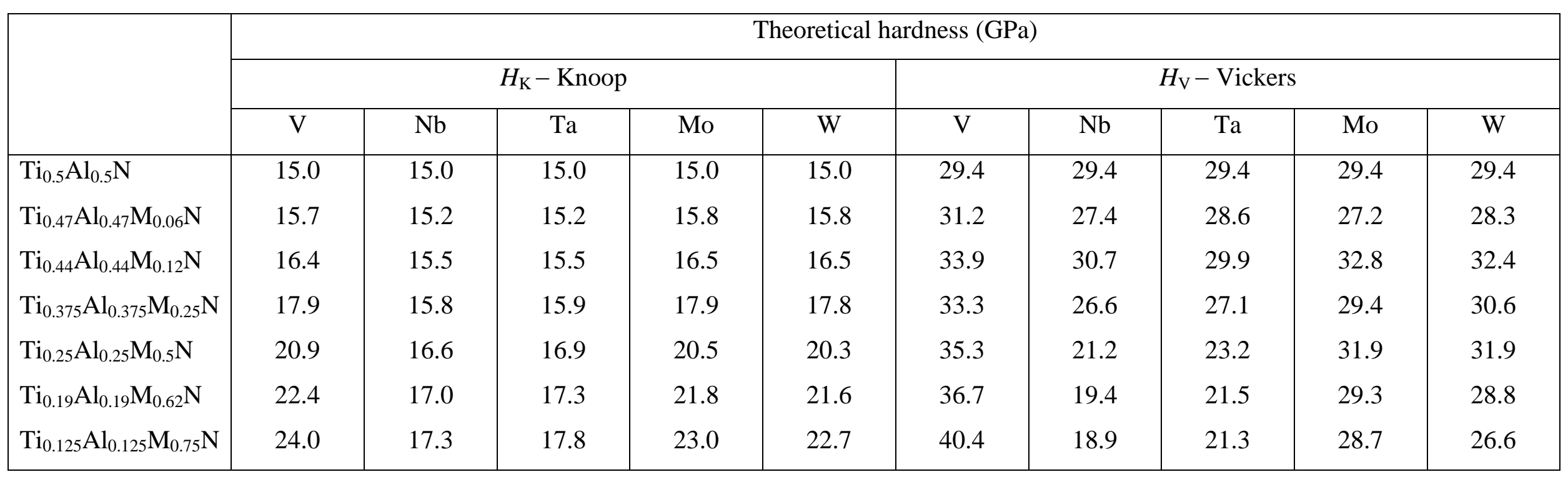


To control the mechanisms responsible for the observed properties in the quarternary alloys presented here, one needs to understand their electronic origins. We employ the approach used in our previous studies of TiN- and VN-based ternary alloys [23, 24], and investigate the electronic signature of applied stresses by examining the charge density distribution of unstrained and strained configurations. The procedure allows us to isolate and identify the effects induced by substitutional, $d$-electron rich, transition metal atoms, upon the existing electronic arrangement in the non-alloyed compound. Our analysis concentrates on $\mathrm{Ti}_{0.25} \mathrm{Al}_{0.25} \mathrm{~W}_{0.5} \mathrm{~N}$, chosen as a representative quarternary system, and two reference ternary alloys, $\mathrm{Ti}_{0.5} \mathrm{~W}_{0.5} \mathrm{~N}$ and $\mathrm{Ti}_{0.5} \mathrm{Al}_{0.5} \mathrm{~N}$, thoroughly studied previously [23, 24]. Nevertheless, the arguments and findings related to $\mathrm{Ti}_{0.25} \mathrm{Al}_{0.25} \mathrm{~W}_{0.5} \mathrm{~N}$ presented next are valid for, and apply to, all quarternary alloys under consideration in this study.

Figure 1 depicts the atomic planes, defined by sequential, parallel atomic layers in the [001] direction, used in the charge density analysis for clarity reasons, given the inherent complexity of quarternary electronic structures. One can immediately see that, given the atomic arrangement, all four planes shown in the figure are needed for quarternary systems. In ternaries, however, Al-W permutations only change periodicity in the first two atomic layers, i.e. the $3^{\text {rd }}$ and $4^{\text {th }}$ planes are repetitions of the first two and are thus not needed in the analysis.

The charge density maps of the unstrained $\mathrm{Ti}_{0.25} \mathrm{Al}_{0.25} \mathrm{~W}_{0.5} \mathrm{~N}$ configuration are shown in Fig. 5. Therein, Fig. 5a and Fig. 5b correspond to planes 1 and 2 cuts in Fig. 1, and map the charge density in W-Ti planes; Fig. 5c and Fig. 5d yield the charge distribution along the $3^{\text {rd }}$ and $4^{\text {th }}$ plane cuts in Fig. 1, i.e. for the $\mathrm{W}-\mathrm{Al}$ planes. As it can be seen, charge near $\mathrm{N}$ and $\mathrm{Ti}$ nuclei has a spherical distribution, indicating that $\mathrm{Ti}-\mathrm{N}$ bonds are mainly ionic (Fig. 5a and Fig. 5b). By contrast, charge around $\mathrm{W}$ nuclei is clearly delocalized and stretched towards both nearest $(\mathrm{N})$ and next-nearest $(\mathrm{W})$ neighbors. This charge distribution points to relatively strong covalent $\mathrm{W}-\mathrm{N}$ and $\mathrm{W}-\mathrm{W}$ bonds formed with $1^{\text {st }}$ and $2^{\text {nd }}$ neighbors in the $\mathrm{W}-\mathrm{Ti}$ planes. 
The covalent character of $\mathrm{W}-\mathrm{W}$ bonds is even more pronounced in the $\mathrm{W}-\mathrm{Al}$ planes, as evidenced by the charge regions connecting W atoms clearly observable in Fig. 5c and Fig. 5d. In these planes, Al-N bonds are highly ionic, fact supported by the absence of charge at $\mathrm{Al}$ sites as a result of its transfer to nearby $\mathrm{N}$ nuclei.

a)
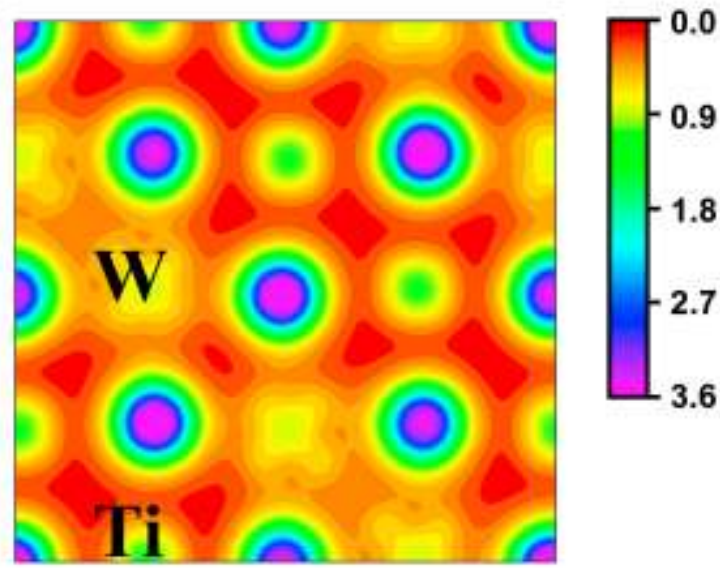

c)

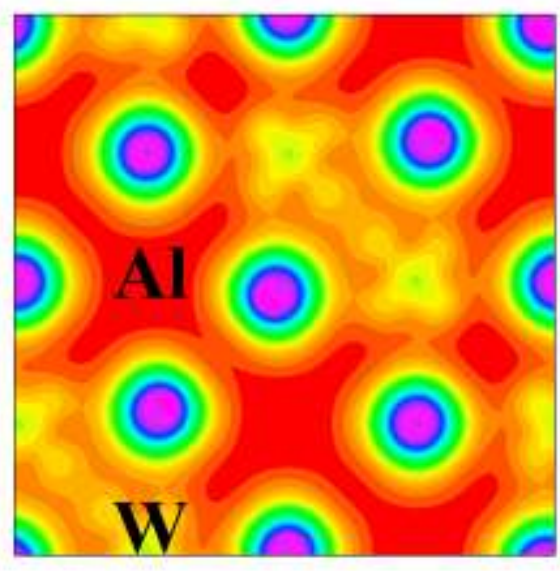

b)

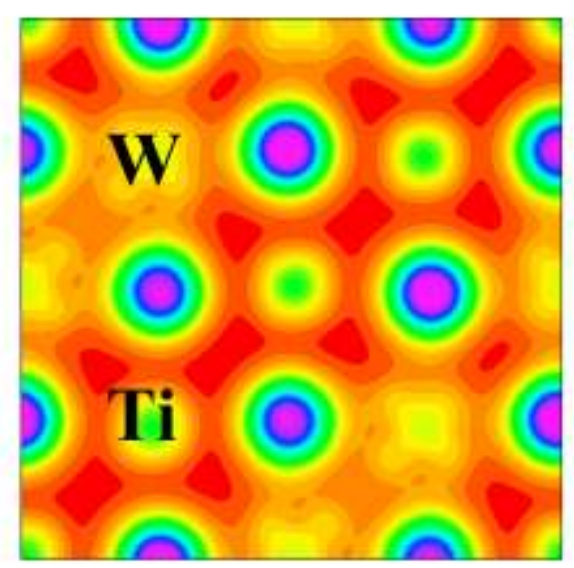

d)

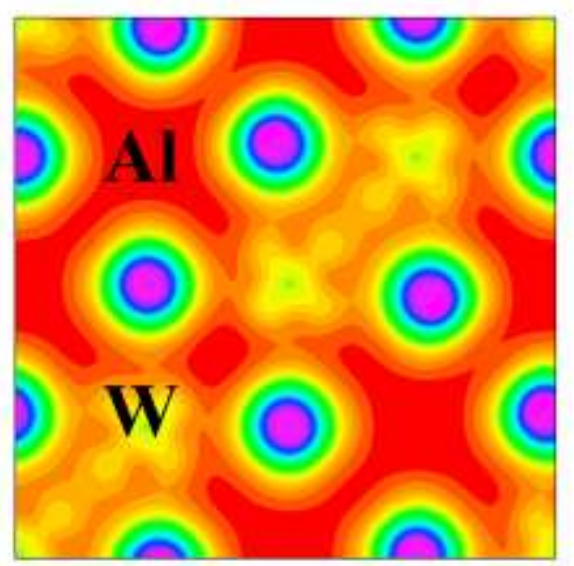
[001]

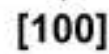

Figure 5. (Color online) Charge density of relaxed $\mathrm{Ti}_{0.25} \mathrm{Al}_{0.25} \mathrm{~W}_{0.5} \mathrm{~N}$ configuration. Color scale units are $\mathrm{e}^{-} / \AA^{3}$.

The charge density maps of unstrained $\mathrm{Ti}_{0.5} \mathrm{~W}_{0.5} \mathrm{~N}$ and $\mathrm{Ti}_{0.5} \mathrm{Al}_{0.5} \mathrm{~N}$ crystals are presented in Fig.6. Here, Fig. 6a and Fig. $6 \mathrm{~b}$ depict the charge distribution in $\mathrm{Ti}_{0.5} \mathrm{~W}_{0.5} \mathrm{~N}$ within the two non-repetitive sequential $\mathrm{W}-\mathrm{Ti}$ atomic planes, and can be compared with the 
charge density within $\mathrm{W}-\mathrm{Ti}$ planes in $\mathrm{Ti}_{0.25} \mathrm{Al}_{0.25} \mathrm{~W}_{0.5} \mathrm{~N}$ (Fig. 5a and Fig. 5b). As one can see, essentially there is no difference between $\mathrm{Ti}-\mathrm{N}$ bonds in the ternary (Fig. 6a and Fig. 6b) and Ti-N bonds in the quarternary (Fig. 5a and Fig. 5b). The main difference between quarternary and ternary systems in the $\mathrm{W}-\mathrm{Ti}$ planes lies in the bonds formed by $\mathrm{W}$ atoms. While in $\mathrm{Ti}_{0.25} \mathrm{Al}_{0.25} \mathrm{~W}_{0.5} \mathrm{~N}$ the $\mathrm{W}-\mathrm{W}$ covalent bonds are clearly visible, i.e. bonds with $2^{\text {nd }}$ neighbors, this is no longer the situation in $\mathrm{Ti}_{0.5} \mathrm{~W}_{0.5} \mathrm{~N}$, case in which the $\mathrm{W}-\mathrm{N}$, and especially $\mathrm{W}-\mathrm{W}$ covalent bonds, appear considerably weaker. In similar fashion, one can compare the charge maps in $\mathrm{Ti}_{0.5} \mathrm{Al}_{0.5} \mathrm{~N}$ (Fig. 6c and Fig. 6d) with that in $\mathrm{Ti}_{0.25} \mathrm{Al}_{0.25} \mathrm{~W}_{0.5} \mathrm{~N}$ (Fig. 5). In this instance, since only $\mathrm{Ti}-\mathrm{Al}$ planes are present in the ternary, the difference with respect to either the $\mathrm{W}-\mathrm{Ti}$ or $\mathrm{W}-\mathrm{Al}$ plane in the quarternary is evident. The $\mathrm{Al}-\mathrm{N}$ bonds are highly ionic, as in $\mathrm{Ti}_{0.25} \mathrm{Al}_{0.25} \mathrm{~W}_{0.5} \mathrm{~N}$ (Fig. 5c and Fig. 5d), while the Ti-N bonds exhibit the typical mixture of ionic-covalent bonds, i.e. essentially unchanged with respect to $\mathrm{Ti}_{0.5} \mathrm{~W}_{0.5} \mathrm{~N}$ and $\mathrm{Ti}_{0.25} \mathrm{Al}_{0.25} \mathrm{~W}_{0.5} \mathrm{~N}$. The main characteristic in this ternary, however, is the total lack of bonds between $2^{\text {nd }}$ neighbors.

As motivated above, our investigation proceeds by analyzing the charge density in the shear strained structures along the [110] direction. The results for the two ternaries considered here are shown in Fig. 7a and Fig. $7 \mathrm{~b}\left(\mathrm{Ti}_{0.5} \mathrm{~W}_{0.5} \mathrm{~N}\right)$, and respectively in Fig. $7 \mathrm{c}$ and Fig. $7 \mathrm{~d}$ $\left(\mathrm{Ti}_{0.5} \mathrm{Al}_{0.5} \mathrm{~N}\right)$. At this point we use the fact that for TiN- and $\mathrm{VN}$-based ternaries alloyed with $\mathrm{Nb} / \mathrm{Ta} / \mathrm{Mo} / \mathrm{W}$, the ductility and toughness enhancement mechanism has already been shown to be a VEC effect, which translated into stronger reference metal $\mathrm{Ti} / \mathrm{V}-\mathrm{N}$, and weaker alloying metal $\mathrm{Nb} / \mathrm{Ta} / \mathrm{Mo} / \mathrm{W}-\mathrm{N}$ bonds $[23,24]$. Upon shearing, these VEC induced bonding changes allow $d$-electron rich $\mathrm{Nb} / \mathrm{Ta} / \mathrm{Mo} / \mathrm{W}$ atoms to interact stronger, leading to increased occupancy of $d-t_{2 g}$ metallic states and the formation of a layered electronic structure, and ultimately, a selective response to strain, respectively shear deformations. These effects are clearly seen here for $\mathrm{Ti}_{0.5} \mathrm{~W}_{0.5} \mathrm{~N}$ in Fig. $7 \mathrm{a}$ and Fig. $7 \mathrm{~b}$. By comparison, the $\mathrm{Ti}_{0.5} \mathrm{Al}_{0.5} \mathrm{~N}$ 
response to shear reflects its primarily ionic bonding structure, and consequently, in terms of charge density distribution, there is essentially no difference between the strained (Fig. 7c and Fig. 7d) and the unstrained (Fig. 6c and Fig. 6d) configurations. To a large extent, this type of "bonding" response to shearing explains the stiff/brittle nature of $\mathrm{Ti}_{0.5} \mathrm{Al}_{0.5} \mathrm{~N}$ [23].

a)
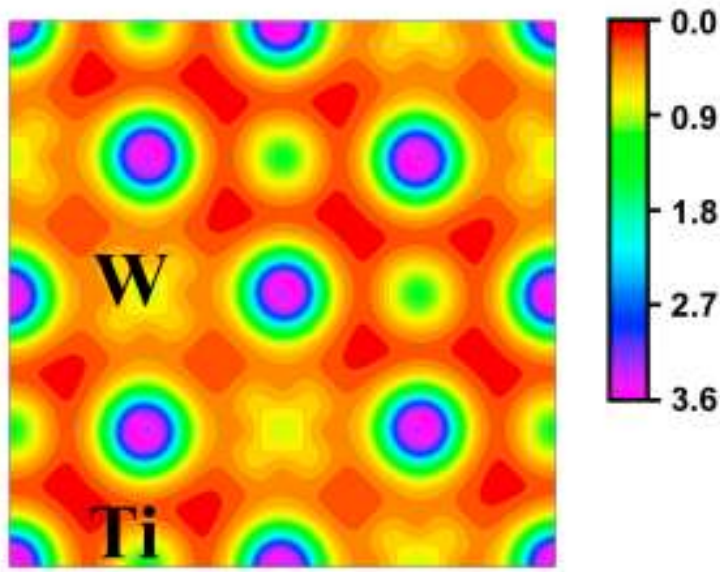

c)

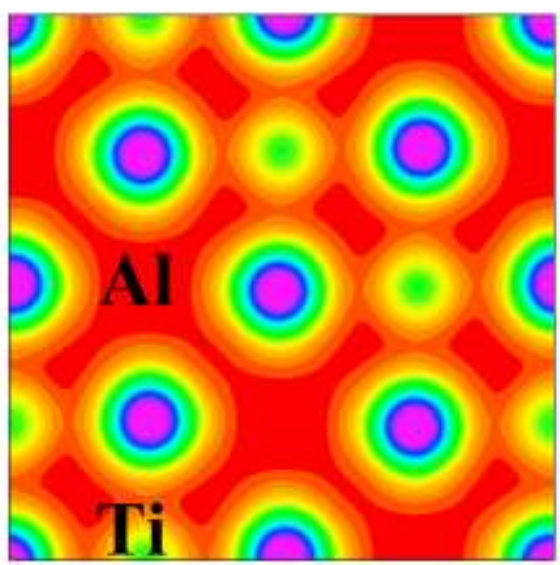

b)

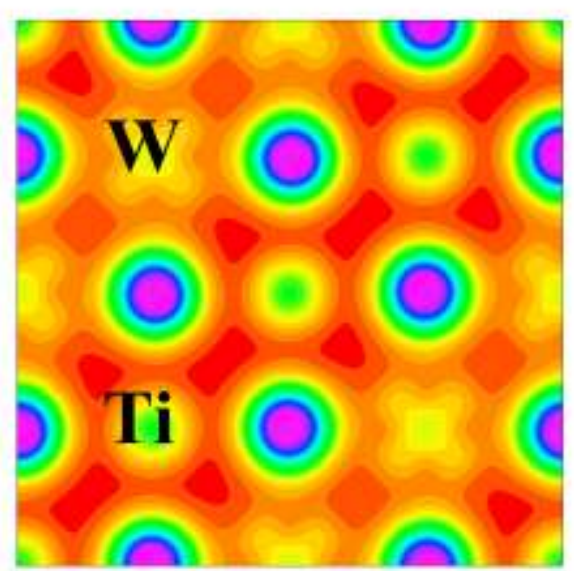

d)

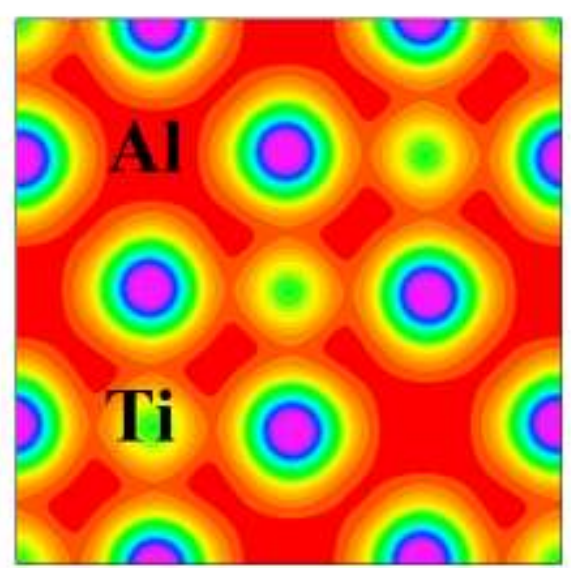

[001]

\section{[100]}

Figure 6. (Color online) Charge density of relaxed structures: $\operatorname{Ti}_{0.5} \mathrm{~W}_{0.5} \mathrm{~N}$, in (a) and (b); $\mathrm{Ti}_{0.5} \mathrm{Al}_{0.5} \mathrm{~N}$, in (c) and (d). Color scale units are $\mathrm{e}^{-} / \AA^{3}$.

The formation of the layered electronic structure in $\mathrm{Ti}_{0.25} \mathrm{Al}_{0.25} \mathrm{~W}_{0.5} \mathrm{~N}$ upon shearing is clearly observed in the comparable W-Ti (Fig. 8a) and W-Al planes (Fig. 8c), which correspond to planes 1 and 3 cuts in Fig. 1 . Here, as for $\operatorname{Ti}_{0.5} \mathrm{~W}_{0.5} \mathrm{~N}$, alternating layers with high/low charge density are oriented along the [1 $\overline{1} 0]$ direction, i.e. normal to the applied 
strain, and in fact, this signature of enhanced ductility is even more pronounced in the quarternary case. In the vicinal W-Ti (Fig. 8b) and W-Al (Fig. 8d) layers, along planes 2 and 4 cuts in Fig. 1, shearing induces an expected $\mathrm{W}-\mathrm{W}$ bonds length elongation and weakening of these covalent bonds, as charge is transferred primarily towards $\mathrm{N}$ nuclei. Similar effects are observed in $\mathrm{Ti}_{0.5} \mathrm{~W}_{0.5} \mathrm{~N}$ (Fig. $7 \mathrm{~b}$ ) and, to a lesser extent, in $\mathrm{Ti}_{0.5} \mathrm{Al}_{0.5} \mathrm{~N}$ (Fig. $7 \mathrm{~d}$ ). It then becomes clear that the formation of the layered electronic arrangement and overall redistribution of charge induced in $\mathrm{Ti}_{0.25} \mathrm{Al}_{0.25} \mathrm{~W}_{0.5} \mathrm{~N}$ upon shearing will allow, as shown for ternaries, a selective response to normal and shear stresses. This eloquently demonstrates that the electronic mechanism for enhanced ductility is equally active in quarternary systems. We note that equivalent $d-t_{2 \mathrm{~g}}$ metallic interactions were shown to be induced upon shearing in MAX phase $\mathrm{M}_{2} \mathrm{AN}$ nitrides [45], $\mathrm{M}_{2} \mathrm{AlC}$ carbides [46], and in carbonitrides [47].

a)

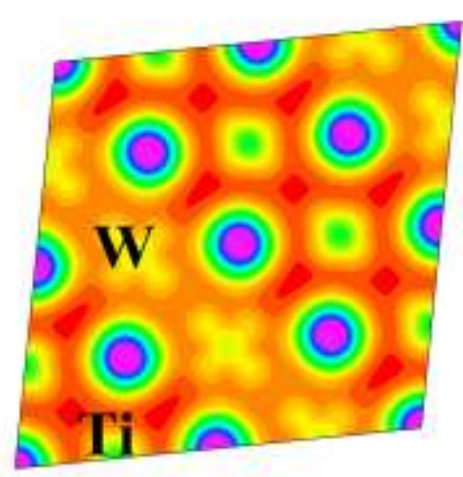

c)

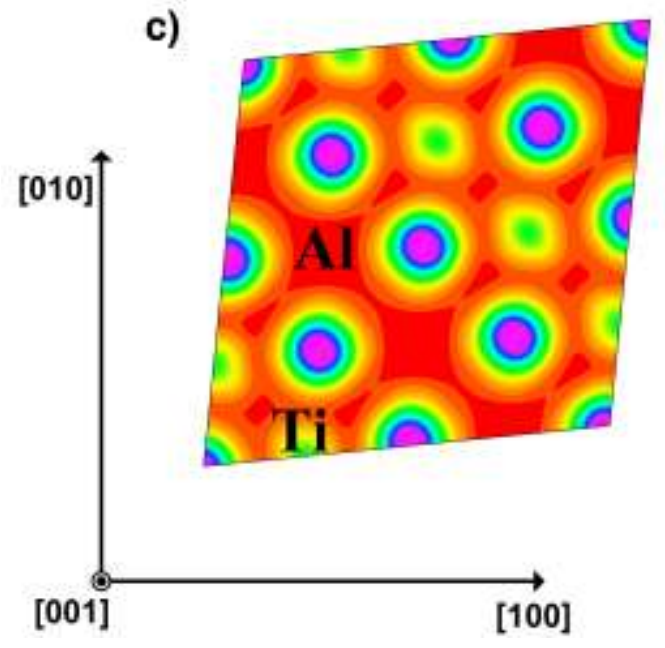

b)

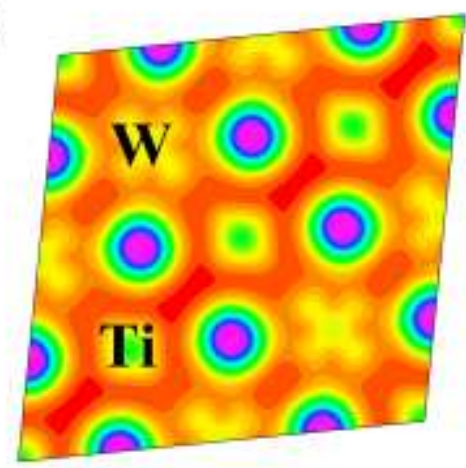

d)

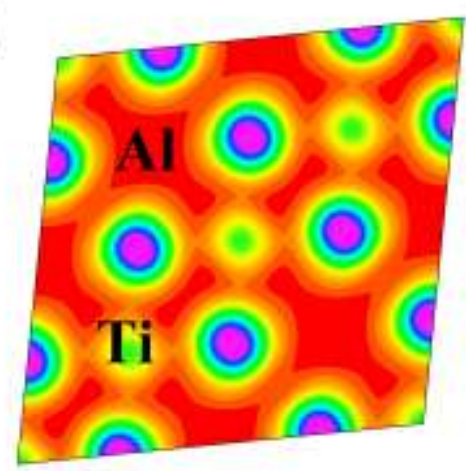

Figure 7. (Color online) Charge density of shear strained (10\%) structures: $\mathrm{Ti}_{0.5} \mathrm{~W}_{0.5} \mathrm{~N}$, in (a) and (b); $\mathrm{Ti}_{0.5} \mathrm{Al}_{0.5} \mathrm{~N}$, in (c) and (d). Color scale units are $\mathrm{e}^{-} / \AA^{3}$. 
a)

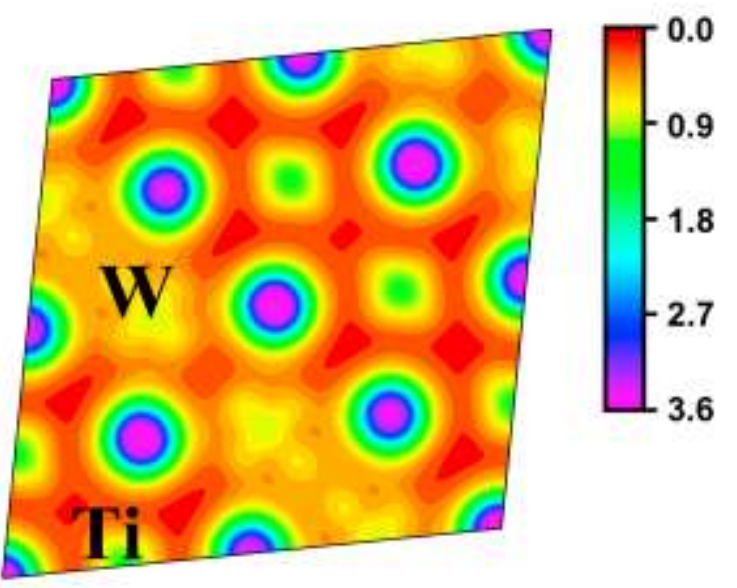

c)

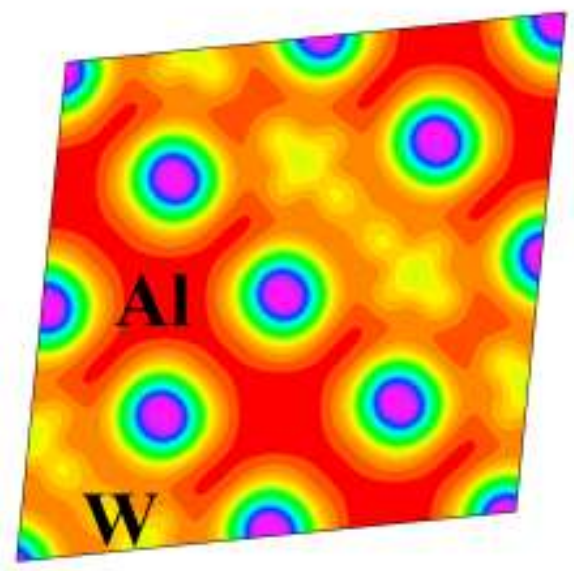

b)

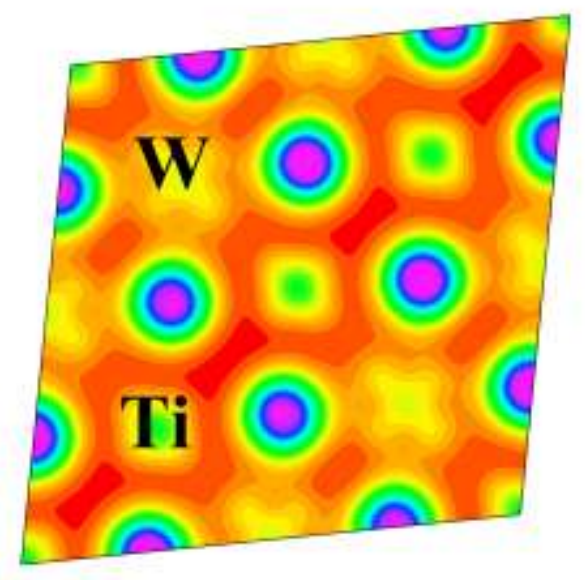

d)

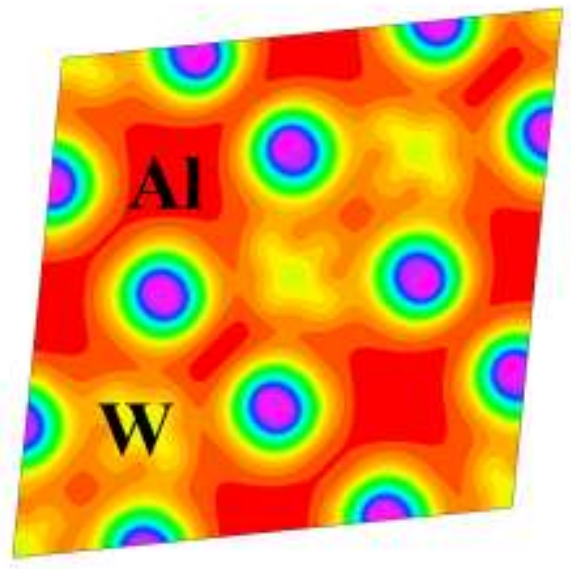
[001]

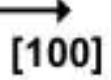

Figure 8. (Color online) Charge density of shear strained (10\%) $\mathrm{Ti}_{0.25} \mathrm{Al}_{0.25} \mathrm{~W}_{0.5} \mathrm{~N}$ configuration. Color scale units are $\mathrm{e}^{-} / \AA^{3}$.

To quantify the changes induced in bonding by alloying $\mathrm{Ti}_{0.5} \mathrm{Al}_{0.5} \mathrm{~N}$ we use the COOP analysis. We report the results for $\left(\mathrm{Ti}_{0.5} \mathrm{Al}_{0.5}\right)_{1-\mathrm{x}} \mathrm{W}_{\mathrm{x}} \mathrm{N}$ alloys, chosen as representative quarternary systems, and note that similar trends are observed for all other alloying combinations. In Fig. 9 we plot the COOP results obtained from nearest neighbor metal $-\mathrm{N}$ orbitals for each $\mathrm{W}$ concentration, where metal denotes interactions with $\mathrm{W}, \mathrm{Ti}$ and $\mathrm{Al}$. The positive COOP peaks located in the $[-22,-19] \mathrm{eV}$ range correspond to $\sigma s(\mathrm{~N})-s($ metal $)$ bonding states, while those within the $[-12,-6] \mathrm{eV}$ interval correspond to $\sigma p(\mathrm{~N})-d-e_{g}(\mathrm{~W}, \mathrm{Ti})$ and $\sigma p(\mathrm{~N})-p($ metal $)$ bonding states. The negative COOP values at Fermi level denote $\pi^{*}$ 
$p(\mathrm{~N})-d-t_{2 g}(\mathrm{~W}, \mathrm{Ti})$ anti-bonding states. As it can be seen, the general trend in this case is that $1^{\text {st }}$ neighbor bonds are essentially not affected by the addition of $\mathrm{W}$ in $\mathrm{Ti}_{0.5} \mathrm{Al}_{0.5} \mathrm{~N}$.

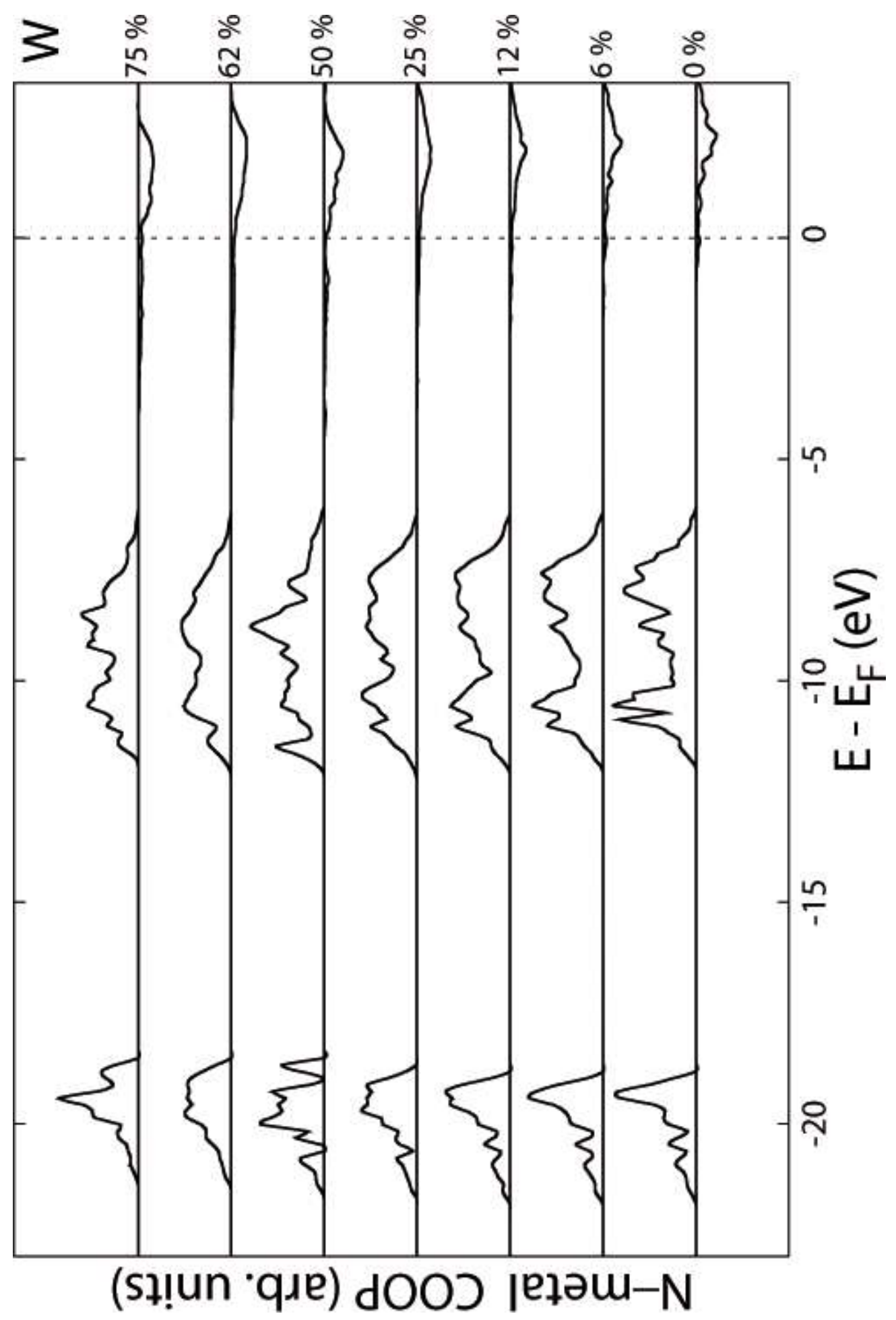

Figure 9. COOP results for $1^{\text {st }}$ neighbor interactions in $\left(\mathrm{Ti}_{0.5} \mathrm{Al}_{0.5}\right)_{1-x} \mathrm{~W}_{x} \mathrm{~N}$.

The results for $2^{\text {nd }}$ neighbor interactions, which correspond to metal-metal orbitals overlap, are shown in Fig. 10. Here, the COOP peaks corresponding to $\sigma s($ metal $)-s($ metal $)$ 


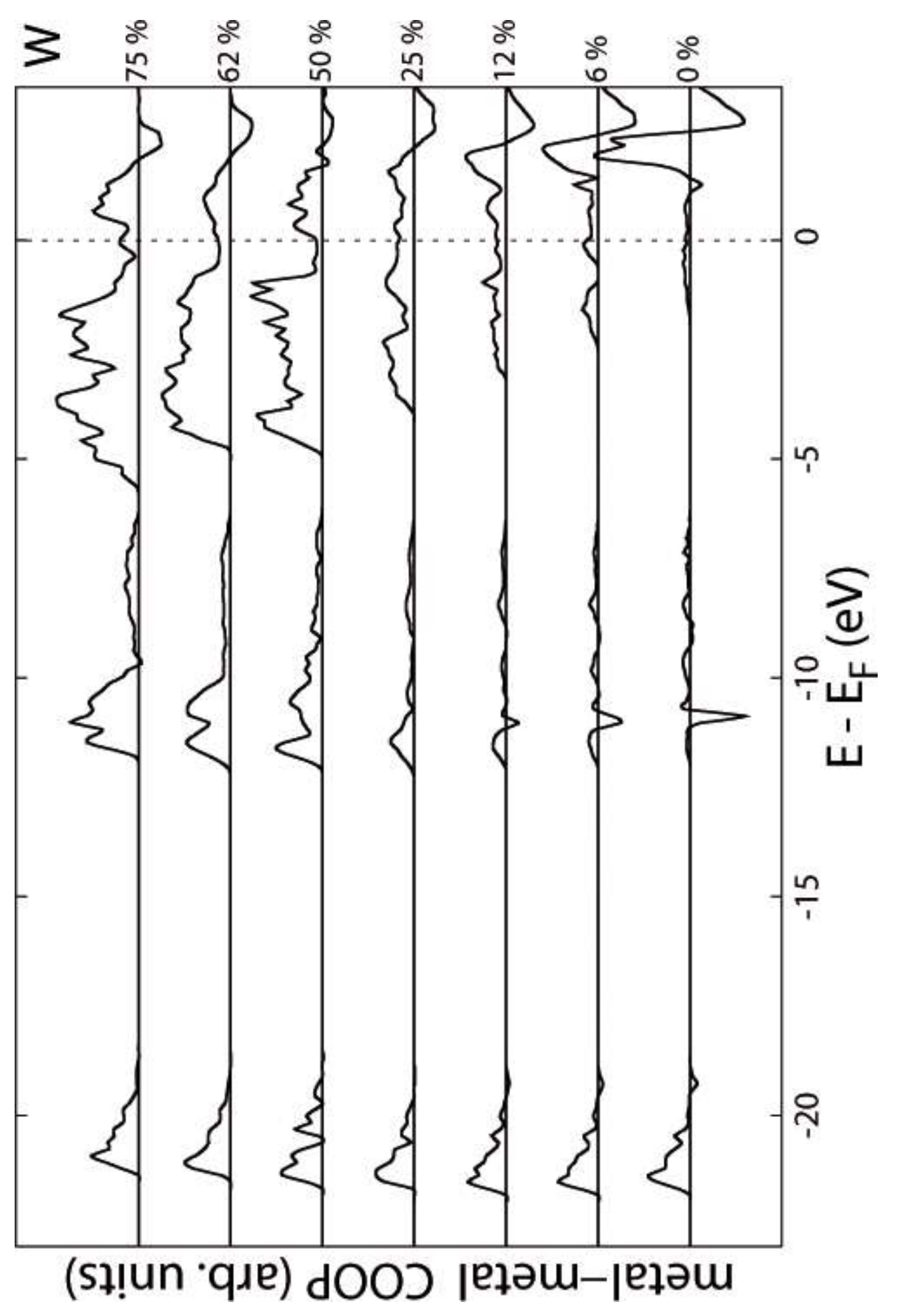

Figure 10. COOP results for $2^{\text {nd }}$ neighbor interactions in $\left(\mathrm{Ti}_{0.5} \mathrm{Al}_{0.5}\right)_{1-x} \mathrm{~W}_{x} \mathrm{~N}$.

bonding states form in the [-22, -19] eV energy range, and essentially, do not change with increasing $\mathrm{W}$ concentration. However, COOP peaks located in the $[-12,-6] \mathrm{eV}$ interval, 
obtained from the superposition of bonding $\sigma d-t_{2 g}(\mathrm{~W}, \mathrm{Ti})-s($ metal $)$ and anti-bonding $\sigma^{*}$ $s($ metal $)-s($ metal $)$ states, are clearly affected by the amount of $\mathrm{W}$ present in the alloy. Increasing $\mathrm{W}$ concentrations result in a gradually dominant $\sigma d-t_{2 g}-s$ bonding component, which eventually overcomes the initially prevalent $\sigma^{*} s-s$ anti-bonding states (note the initial anti-bonding states in $\mathrm{Ti}_{0.5} \mathrm{Al}_{0.5} \mathrm{~N}$ in this range at the bottom of Fig. 10). Similar, but considerably larger variations, are observed for the $\sigma d-t_{2 g}(\mathrm{~W}, \mathrm{Ti})-d-t_{2 g}(\mathrm{~W}, \mathrm{Ti})$ bonding states near Fermi level. In this case, it becomes evident that practically non-bonding states in $\mathrm{Ti}_{0.5} \mathrm{Al}_{0.5} \mathrm{~N}$ are transformed to primarily bonding in $\left(\mathrm{Ti}_{0.5} \mathrm{Al}_{0.5}\right)_{1-x} \mathrm{~W}_{x} \mathrm{~N}$ alloys as $\mathrm{W}$ concentration increases. This effect, which is strongly connected to the higher VEC in quarternaries, demonstrates the key role played by $2^{\text {nd }}$ neighbor interactions in these compounds.

The general trends in bonding induced in $\left(\mathrm{Ti}_{0.5} \mathrm{Al}_{0.5}\right)_{1-x} \mathrm{M}_{x} \mathrm{~N}$ alloys are summarized in Table 7, where we list the integrated (ICOOP) results of our COOP analysis for $1^{\text {st }}$ and $2^{\text {nd }}$ neighbor interactions, in all alloys and for all concentrations. In the table, one can clearly see that, with the exception of the V-based quarternaries, $1^{\text {st }}$ neighbor metal $-\mathrm{N}$ bonds strength decreases with increasing $M$ content. At the same time, increased $M$ concentrations lead to significantly stronger $2^{\text {nd }}$ neighbor metal-metal bonds in all alloying combinations. This VEC induced bonding adjustment, as demonstrated previously [24], will accommodate and allow dislocation glide along certain slip planes, enhance ductility, and hence the ability of materials to comply with mechanical stresses. These results demonstrate that the bonding mutation reported herein equates overall to significantly reduced bond directionality in alloys, a primary barrier to dislocation motion and brittleness precursor, and explain the role played by the VEC in enhancing ductility and toughness in these alloys. 
TABLE 7.

ICOOP results for each $\left(\mathrm{Ti}_{0.5} \mathrm{Al}_{0.5}\right)_{1-x} \mathrm{M}_{x} \mathrm{~N}$ alloy and concentration.

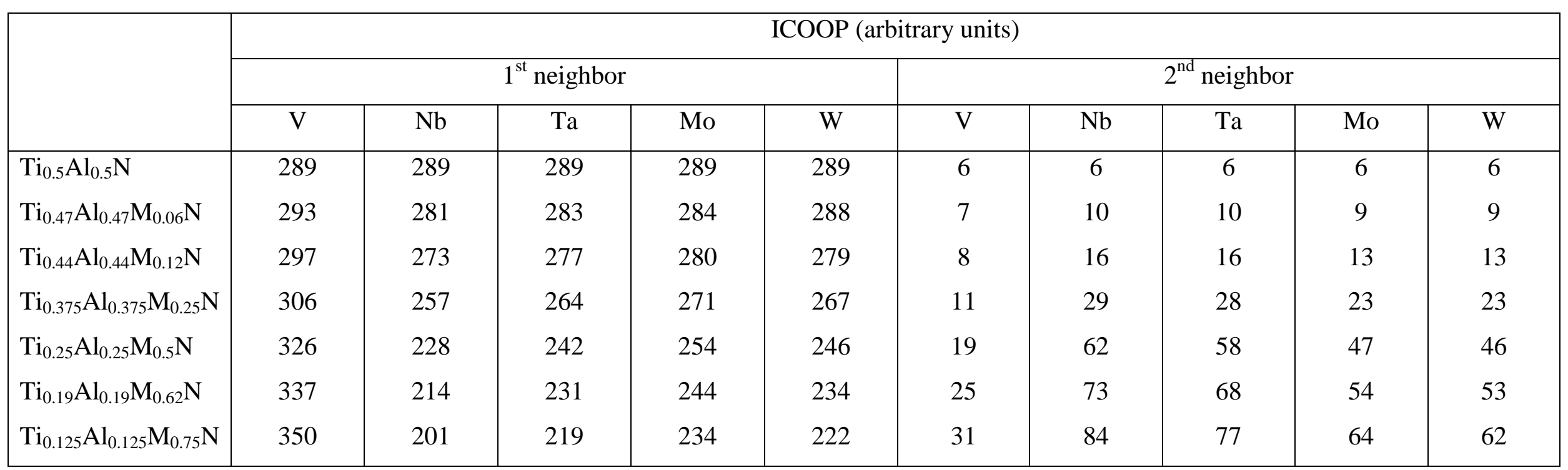




\section{Conclusions}

We investigate a number of $\left(\mathrm{Ti}_{0.5} \mathrm{Al}_{0.5}\right)_{1-x} \mathrm{M}_{x} \mathrm{~N}$ quarternary alloys, obtained by alloying TiAlN with $\mathrm{M}=\mathrm{V}, \mathrm{Nb}, \mathrm{Ta}, \mathrm{Mo}$, and $\mathrm{W}$ for $0.06 \leq x \leq 0.75$. DFT predicted mechanical properties indicate that in most compounds one can significantly increase ductility and retain high hardness, at least comparable to that of TiAlN. Our extensive electronic structure and bond strength analysis demonstrate that this complex combination of mechanical properties, which equates to improved toughness, is a primarily VEC effect, leading to enhanced occupancy of $d-t_{2 g}$ metallic states and overall reduction in bond directionality. This effect is more pronounced at increasing $\mathrm{M}$ concentrations and allows for a selective material response to normal and shear stresses. The findings presented herein suggest new avenues for the synthesis of hard, yet tough, ceramic coatings, by tuning the VEC of alloying elements to optimize the hardness/toughness ratio in relevant applications.

\section{Acknowledgements}

This work was supported by the Swedish Research Council (VR) and the Swedish Strategic Research Foundation (SSF) Program on Materials Science and Advanced Surface Engineering. All calculations were performed using the resources provided by the Swedish national infrastructure for computing (SNIC), on the Neolith and Kappa clusters located at the National Supercomputer Centre (NSC) in Linköping. 


\section{References}

[1] G.E. Dieter, Mechanical Metallurgy, McGraw-Hill, 1976.

[2] J.F. Knott, Fundamentals of Fracture Mechanics, John Wiley-Halsted Press, New York, 1973.

[3] P.H. Mayrhofer, C. Mitterer, L. Hultman, H. Clemens, Progress in Materials Science 51/8 (2006) 1032.

[4] L. Hultman, Nanostructured Coatings, Springer, New York, 2006.

[5] A. Raveh, I. Zukerman, R. Shneck, R. Avni, I. Fried, Surface \& Coatings Technology 201/13 (2007) 6136.

[6] P. Steyer, A. Mege, D. Pech, C. Mendibide, J. Fontaine, J.F. Pierson, C. Esnouf, R. Goudeau, Surface \& Coatings Technology 202/11 (2008) 2268.

[7] M. Stueber, H. Holleck, H. Leiste, K. Seemann, S. Ulrich, C. Ziebert, Journal of Alloys and Compounds 483/1-2 (2009) 321.

[8] W.K. Tredway, Science 282/5392 (1998) 1275.

[9] W.J. Clegg, Science 286/5442 (1999) 1097.

[10] A.H. Sherry, T.J. Marrow, Mechanical properties and fracture of materials, Shreir's Corrosion, 2010.

[11] D.P.H. Hasselman, Journal of the American Ceramic Society 52/11 (1969) 600.

[12] R.O. Ritchie, Science 320/5875 (2008) 448.

[13] T. Zhu, J. Li, Progress in Materials Science 55/7 (2010) 710.

[14] K. Lu, Science 328/5976 (2010) 319.

[15] S.H. Zhang, E. Byon, M.X. Li, Y.Z. He, F. Cai, L. Wang, H.S. Li, S.H. Si, Thin Solid Films 519/6 (2011) 1901.

[16] S. Zhang, D. Sun, Y.Q. Fu, H.J. Du, Surface \& Coatings Technology 167/2-3 (2003) 113.

[17] D.C. Hofmann, J.Y. Suh, A. Wiest, G. Duan, M.L. Lind, M.D. Demetriou, W.L. Johnson, Nature 451/7182 (2008) 1085.

[18] S. Zhang, H.L. Wang, S.E. Ong, D. Sun, X.L. Bui, Plasma Processes and Polymers 4/3 (2007) 219.

[19] J.N. Ding, Y.G. Meng, S.Z. Wen, Thin Solid Films 371/1-2 (2000) 178. 
[20] S. Zhang, D. Sun, Y.Q. Fu, H.J. Du, Surface \& Coatings Technology 198/1-3 (2005)

[21] S. Kamran, K.Y. Chen, L. Chen, Physical Review B 79/2 (2009) 024106.

[22] T. Dasgupta, U.V. Waghmare, A.M. Umarji, Physical Review B 76/17 (2007) 174110.

[23] D.G. Sangiovanni, V. Chirita, L. Hultman, Physical Review B 81 (2010) 104107.

[24] D.G. Sangiovanni, L. Hultman, V. Chirita, Acta Materialia 59/5 (2011) 2121.

[25] G. Kresse, J. Hafner, Physical Review B 47/1 (1993) 558.

[26] J.P. Perdew, Y. Wang, Physical Review B 45/23 (1992) 13244.

[27] P.E. Blöchl, Physical Review B 50/24 (1994) 17953.

[28] F. Tian, J. D'Arcy-Gall, T.Y. Lee, M. Sardela, D. Gall, I. Petrov, J.E. Greene, Journal of Vacuum Science \& Technology A 21/1 (2003) 140.

[29] H.J. Monkhorst, J.D. Pack, Physical Review B 13/12 (1976) 5188.

[30] R. Hoffmann, Solids and Surfaces: A Chemist's View of Bonding in Extended Structures, Wiley-VCH, 1988.

[31] A. Šimůnek, Physical Review B 75/17 (2007) 172108.

[32] X.J. Guo, L. Li, Z.Y. Liu, D.L. Yu, J.L. He, R.P. Liu, B. Xu, Y.J. Tian, H.T. Wang, Journal of Applied Physics 104/2 (2008) 023503.

[33] D.G. Sangiovanni, Linköping University, Linköping University Electronic Press, http://liu.diva-portal.org/smash/get/diva2:378914/FULLTEXT01, 2011.

[34] T. Reeswinkel, D.G. Sangiovanni, V. Chirita, L. Hultman, J.M. Schneider, Surface and Coatings Technology 205/20 (2011) 4821.

[35] R. Rachbauer, D. Holec, M. Lattemann, L. Hultman, P.H. Mayrhofer, International Journal of Materials Research 102/6 (2011) 735.

[36] H. Polakova, J. Musil, J. Vlcek, J. Allaart, C. Mitterer, Thin Solid Films 444/1-2 (2003) 189.

[37] K. Kutschej, P.H. Mayrhofer, M. Kathrein, P. Polcik, C. Mitterer, Surface \& Coatings Technology 188 (2004) 358.

[38] M. Pfeiler, K. Kutschej, M. Penoy, C. Michotte, C. Mitterer, M. Kathrein, Surface \& Coatings Technology 202 (2007) 1050.

[39] M. Pfeiler, K. Kutschej, M. Penoy, C. Michotte, C. Mitterer, M. Kathrein, International Journal of Refractory Metals and Hard Materials 27/2 (2009) 502.

[40] R. Rachbauer, D. Holec, P.H. Mayrhofer, Applied Physics Letters 97/15 (2010) 151901.

[41] D.G. Pettifor, Materials Science and Technology 8/4 (1992) 345.

[42] S.F. Pugh, Philosophical Magazine 45 (1954) 823.

[43] A. Šimůnek, J. Vackar, Physical Review Letters 96/8 (2006) 085501.

[44] F.M. Gao, J.L. He, E.D. Wu, S.M. Liu, D.L. Yu, D.C. Li, S.Y. Zhang, Y.J. Tian, Physical Review Letters 91/1 (2003) 015502.

[45] Z.M. Sun, D. Music, R. Ahuja, J.M. Schneider, Physical Review B 71/19 (2005) 193402.

[46] J. Emmerlich, D. Music, A. Houben, R. Dronskowski, J.M. Schneider, Physical Review B 76/22 (2007) 224111.

[47] S.H. Jhi, J. Ihm, S.G. Louie, M.L. Cohen, Nature 399/6732 (1999) 132. 